\author{
Visión Electrónica \\ Más que un estado sólido \\ https: / doi.org/10.14483/issn.2248-4728
}

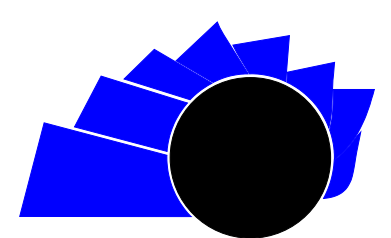

VISIÓN ELECTRÓNICA

A CURRENT VISION

\title{
Internet of things, reality of a connected world
}

\author{
Internet de las cosas, realidad de un mundo conectado
}

\begin{abstract}
Andrea Liliana Fagua-Fagua ${ }^{(1)}{ }^{1}$, José Custodio Najar-Pacheco (iD) 2
\end{abstract}
INFORMACIÓN DEL ARTÍCULO

Historia del artículo:

Enviado: 02/05/2020

Recibido: 12/05/2020

Aceptado: 09/07/2020

\section{Keywords:}

Connectivity

Data

Internet of things (IoT)

Security

Sensors

Technology

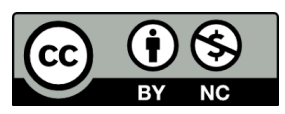

Palabras clave:

Conectividad

Datos

Internet de las cosas (IoT)

Seguridad

Sensores

Tecnología

\begin{abstract}
In recent years, the internet has evolved to become the Internet of Things (IoT), one of the most important and significant inventions of all humanity, generating a direct impact on the way of living, thinking and acting. It is one of the most used terms by anyone who thinks about smart connectivity, it is the answer to connecting to the network an incredible number of people and everyday objects equipped with sensors, actuators and communication technologies, which exchange information from the physical world through Internet, offering real-time data monitored through the network. With IoT, more and more companies integrate sensors that supply information on almost everything that can be measured, therefore, the amount of data circulating on networks grows exponentially, as do security measures and recommendations. Smart cities are an example of the benefits that IoT brings, with the improvement of people's quality of life, services that are offered in an efficient, sustainable way and with excellent ideas for innovation.
\end{abstract}

\section{RESUMEN}

En los últimos años, internet ha evolucionado para convertirse en internet de las cosas (IoT) una de las invenciones más importantes y significativas de toda la humanidad, generando un impacto directo en la forma de vivir, pensar y actuar. Es uno de los términos más utilizados por todo aquel que piensa en conectividad inteligente, es la respuesta de conectar a la red un número increíble de personas y objetos cotidianos equipados con sensores, actuadores y tecnologías de comunicación, que intercambian información del mundo físico a través de internet, ofreciendo datos en tiempo real monitoreados a través de la red. Con IoT, cada vez más empresas integran sensores que suministran información de casi todo los que se puede medir, por tanto, la cantidad de datos que circulan por las redes crece de forma exponencial al igual que las medidas de seguridad y las recomendaciones. Las ciudades inteligentes son ejemplo de los beneficios que trae IoT, con mejoramiento de la calidad de vida de las personas, servicios que se ofrecen de forma eficiente, sostenible y con excelentes ideas de innovación.

\footnotetext{
${ }^{1}$ BSc. in Electronic Engineering, Universidad Incca de Colombia, Colombia. MSc. in Strategic Direction in Telecommunications, Universidad Iberoamericana Internacional, Puerto Rico. Current position: Fundación Universitaria Juan de Castellanos, Colombia. afagua@jdc.edu.co

2 BSc. in Systems Engineering, Universidad de Boyacá, Colombia. Specialist in telematics, Universidad de Boyacá, Colombia. Specialist in Telecommunications management, Universidad Central de Bogotá, Colombia. MSc. In Informatic Security, Universidad Internacional de la Rioja, España. Current position: Professor at Fundación Universitaria Juan de Castellanos, Colombia. E-mail: jnajar@jdc.edu.co
} 


\section{Introduction}

The Internet is the most popular network in the world, the largest source of information in the world, in essence is a network of communications and services [1], thousands of machines and devices linked for the transportation of information worldwide [2]. By the years 96 and 97 , the Internet was unknown to many people, no one could imagine the spread that was going to have over the years [3]. Nowadays this technology is revolutionary and widely extended facilitating the interaction between people, institutions, services and companies. Internet has not only affected humanity in an overwhelming way, but also education, communications, business,science, government and others [4]. The Internet of Things (IoT) represents the evolution of the internet and promises to close the gaps between rich and poor people [5].

IoT is important in the global technological development, since it will maximize the interconnection between people and objects to the network in order to create intelligent environments. The technologies of sensors and devices that support IoT are large and is in constant evolution [6]. This means millions of linked devices generating huge amounts of data, which must be stored, processed and presented in a systematized way, which implies the use of devices and increasingly advanced technological resources [7]. Incorporating IoT represents the evaluation of a series of parameters at the level of information security, software architecture and hardware, intelligent devices, communications networks and necessary elements that guarantee the collection of data without human intervention. IoT will have an effect on the lives of people, companies and the way of doing business [8].

\section{What is Internet of things}

Internet of Things (IoT) is a global infrastructure for the information society, a world connected to intelligent devices. People as objects can connect at any time and place to the network, to access advanced services through the interconnection of things (physical and virtual), based on the interoperability of existing and future technologies and communications [9]. The integration of sensors and intelligent devices arranged in everyday objects, play an important role in the evolution of IoT, since they communicate each other with minimum energy consumption and delivering a large amount of data [10]. IoT changes everything, it is a technology that will revolutionize industry, services, cities, agriculture [11], its potential is the ability to combine data, processes and objects from sensors, advanced telecommunications networks and processes analytics based on Big Data and managed by computer equipment for the benefit of human beings [12].

Any object will be disposed to being connected and revealed in the network, making inexhaustible sources of information [13]. The exchange of information between objects and devices will be a reality [14]. We are in the age of data, so the need arises from human beings to feel that they can control each and every one of the movements of the network, establishing true challenges such as smart cities, buildings that control their temperature, clothing that informs about the state of its users, wellbeing in health with the control of monitored diseases and a myriad of elements that will offer information through the internet [15]. It is expected to do a proactive management in the different areas of daily life, in the case of health, to manage the population to keep it healthy and, in some way, keep the diseases stable, carrying out more preventive measures, than intervention measures [16].

The internet of things is important, since it allows the digitalization of the physical world, economic growth, smart cities, rational and efficient use of resources, development of Big Data, artificial intelligence, a new economic order, traceability and control, development of new companies, requirements for new advances in computing, new concepts of efficiency and management, a trillions dollar market, a whole world to connect, explore and know [17].

\subsection{Effect of the internet of things on business and society}

This phenomenon of IoT affects daily life and the usual behavior of human beings, establishes a great impact on society and business, as information and people are increasingly connected [18]. Technology assists as a collaborative tool and makes decisions in a world in which the physical and the digital field converge [19]. In the banking field, more and more people carry out operations through the Internet and also by using mobile devices, platforms that have become an accessible tool for any user to manage bank payments and transfers, every time there will be less need to use cash, by using only our mobile device and applications will be enough [20].

The effect of the IoT on the media gives us a vision about the types of work and economic opportunities that will be created [20]. Economic models have been created towards services. IoT will significantly accelerate the transformation towards service economies, which are 
taking place all over the world [21], the private sector is where the internet of things is becoming increasingly popular, the mass production industry, temperature sensors, production control, assembly robots, everything is connected to the internet. Many cities incorporate technology based on IoT, which allows greater flexibility in operation and monitoring in real time, as examples we have: environmental control, it also integrates IoT technology since it allows access from almost anywhere to meteorological, seismic sensors information, atmospheric; and with the acquired data, to be able to take measures in any case. It also adds to the network, the control of urban infrastructure, control of traffic lights, bridges, railways, everything based on IoT [22].

The Figure 1 shows the implementation of the internet of things in different industries

Figure 1: Speed of Internet of things implementation in the industry [23].

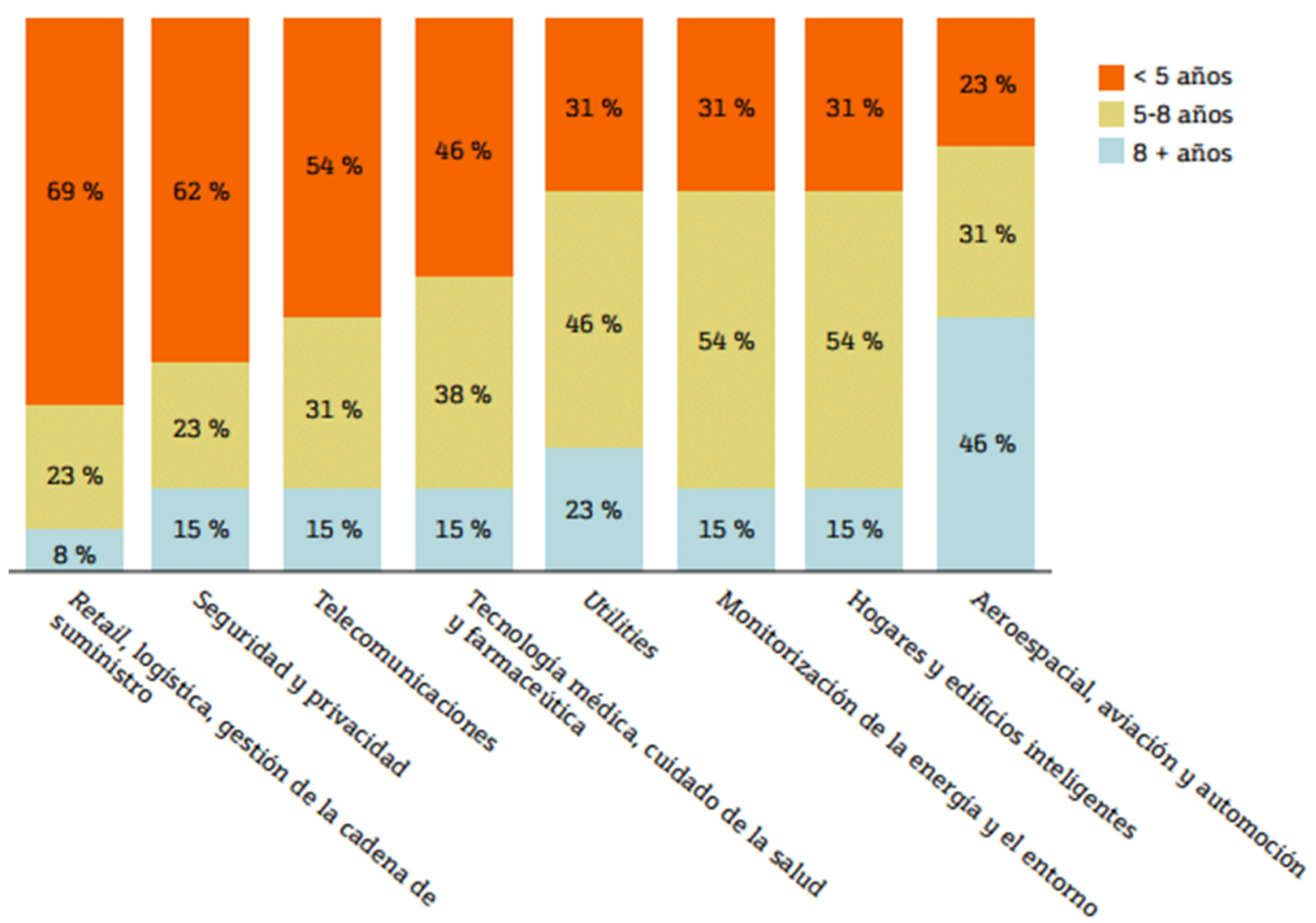

2.2. Implications of the internet of things, current situation of a promising technology

Internet of things is a reality with many promises in a near future, which is possible thanks to the technology that has been developed. IoT is already here, nanotechnology and technological advances in all fields allow to use as a tool and connect almost any object with a wide variety of applications [24]. The adoption of IoT on a global scale, also requires facing other technical issues such as interoperability and standardization, which must be resolved in order for this new paradigm to be implemented in its full dimension and, of course, to all these challenges. that to add the obligation to guarantee the protection of data and the privacy, indispensable element for any technological advance of this level [25].

To enable the use of IoT by users, three phenomena have occurred; one of them, is the miniaturization, that allows to reduce the size of the components of the 
computers or devices, making them smaller and smaller, with greater power and efficiency; second, overcoming the limitations of mobile telephony infrastructure; third, the development of applications and services, which allow the use of the large amount of information generated from the IoT [26].

\subsection{Big data and internet of things}

The data produced in the industrial sector, contribute to transform the business model into companies, beyond its production model itself [27]. To be able to adapt to these changes and increase the amount of value provided to the consumer of their products, it is necessary for companies to take significant progress in the field of information and communication technology, Big data and IoT [28]. The incorporation of Big data for the process of millions of data in real time, and IoT for the interconnection of everything through sensors, indicates the trend of predictions, based on the analysis of data in a massive way, but having so much information available one of the biggest risks implies in personal privacy [29]. In the near future the market will be full of intelligent devices, detecting the environment where they are and generating a large amount of data, this means in the short term that Io $\mathrm{T}$ will have the largest flow of information that is gathered on the Internet [30].

\subsection{Security in Internet of things}

The implementation of the internet of things by industry and consumers depends on some factors, from a social perspective in relation to privacy and security, due to the proliferation of connected devices that require a drastic increase in the ability to store and process data [31]. The technologies that have set the evolution of the internet of things are: radio frequency identification (RFID) and wireless sensor networks, known as "sensor nodes"that, due to their characteristics and design, are the source of many problems of security [32]. In the field of security, for IoT there are not many improvements, considering that it is a topic of special importance, which generates a number of problems and risks [33]. But, simultaneously remains the opportunity to generate new ideas and studies to solve this problem [34]. There are business initiatives that are already using IoT, so they will be forced to invest in security to safeguard their information [35].

\subsection{Challenges and barriers in the internet of things}

The internet of things requires taking into account technical issues such as interoperability and standardization [36], even more we must add the protection of data and privacy, with no question is one of the biggest barriers to show IoT, as people will have to face a change of mind and be aware of what types of data they provide day by day and how these data is used [37]. Another of the challenges that IoT faces in its evolution [38] is the transition of IPV6 and the establishment of common rules so that IoT can emerge definitively [39]. On the other hand, another of the barriers where experts agree is the lack of connectivity infrastructures, as well as the development of new technologies that allow sensors to generate electricity from environmental elements. The Internet of Things faces important challenges, but specialists are already working on solving these problems [40].

\subsection{Internet of things in a near future}

At present, millions of people are connected to the Internet, through different devices such as laptops, mobile devices, servers, routers [41], therefore, the Internet is already a network of things, the number of connected devices currently ascends up to 13,400 million, but by 2020 an increase of $283 \%$ is expected, reaching 38 million connected devices, such as books, telephones, household appliances [42], home automation systems, security systems, video game consoles, among others. In Figure 2, a comparison of the devices connected between 2009-2020 can be seen [43].

Figure 2: Comparison of connected devices 2009-2020 [44].

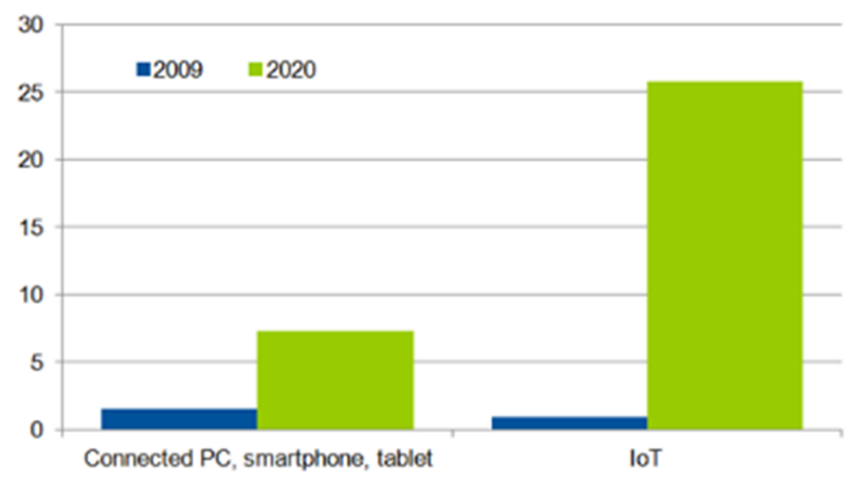

The Internet of Things is about the connection between devices and the exchange of data, along with a network of sensors that share information on aspects of physical reality, generating data that flows through the network and that will have to be processed and analyzed [45], which will require the development of increasingly advanced technologies [46]. 
By 2020, Internet advertising may exceed television advertising [47]. In the future the toilets could analyze the urine and recommend the most appropriate diet, the toothbrush would automatically cite the dentist if it detects problems in the dentition [48]. One of the great impacts of the IoT, would be given in medicine, intelligent electrical networks, automotive industry,manufacturing, smart cities, education, transportation, ecology, agriculture, among others [49]. Among the key technologies for the IoT of the future, it can be found: first, development of technologies in processors [50]: smaller and more powerful; second, sensors [51], elements of hardware that interact with technology, indispensable and almost invisible; finally, communications of low consumption [52].

\section{Conclusions}

The development of IoT, in the future, will depend on the evolution of the devices and the innovation in different fields, as well as the development of applications that will make the productive processes more efficient and will suppose an improvement in the quality of life of the people. The underlying technologies, such as mobile accesses, wireless and fiber optic networks will be the key to the development of IoT.

The speed of adoption of IoT by consumers will depend, to a large extent on privacy and security protocols, where the data shown is increasingly public, worrying, to a great number of users and companies that They should invest more money in information security. IoT should focus on mitigating the risks of society, where the information itself must be transparent for those actors selected and totally invisible to others.

In the future, IoT will lead to the interconnection of thousands of objects and devices connected to different networks, and these devices add multiple sensors that will be installed to record different aspects of physical reality. Wireless sensor networks are the gateway to the Internet of Things (IoT), being able to digitize in real time the largest number of environmental parameters, with the aim of controlling and optimizing the use of resources.

Another area where the connection of things to the network will mean a revolution: is energy, smart electrical networks through connected devices which prices are lower. IoT is a very reality that is evolved, glimpses the immediacy and automatisms.

\section{References}

[1] M. Alcaraz, "Internet de las cosas", Universidad Católica Nuestra Señora la Asunción, 2014.

[2] D. Evans, "Internet de las cosas: Cómo la próxima evolución de Internet lo cambia todo", 2011. [Online]. Available at: https://www.cisco.com/ c/dam/global/es_mx/solutions/executive/ assets/pdf/internet-of-things-iot-ibsg.pdf

[3] J. M. Cueva Lovelle, J. I. Rodríguez Molano and C. E. Montenegro Marin, "Introducción al Internet de las cosas", Redes Ing., vol. 6, pp. 53-59, 2015. https://doi.org/10.14483/2248762X.8505

[4] J. Serrano-cobos, "Tendencias tecnológicas en internet: hacia un cambio de paradigma", Profesional de la información, vol. 25, no. 6, pp. 843-850, 2016. https://doi.org/10.3145/epi.2016.nov.01

[5] L. C. García, "Estudio del impacto técnico y económico de la transición de internet al internet de las cosas (iot) para el caso colombiano", thesis MSc., Universidad Nacional de Colombia, Colombia, 2014.

[6] Fundación de la Innovación Bankinter, "El Internet de las Cosas", 2011. [Online]. Available at: https: //www. fundacionbankinter.org/documents/ 20183/42758/PDF+Internet+de+las+cosas

[7] A. C. Lemus Pinto, C. A. Garzón Sogamoso, y G. M. Tarazona Bermúdez, "Tic en gestión de la cadena de suministro bogotana", Visión electrónica, vol. 10, no. 2, pp. 195-202, dic. 2016. https://doi.org/10. $14483 / 22484728.11653$

[8] S. Otón Tortosa, J. A. Gutiérrez de Mesa, and C. Batanero Ochaita, "Una implementación de afa para la educación virtual accesible", Rev. vínculos, vol. 12 , no. 1 , pp. $6-17$, jun. 2016. https ://doi.org/10. 14483/2322939X.10524

[9] A. Cama Pinto, E. De la Hoz Franco and D. Cama Pinto, "Las redes de sensores inalámbricos y el internet de las cosas", Inge Cuc, vol. 8, no. 1, pp. 163-172, 2012.

[10] D Moya, "Internet de las Cosas (IoT)", Revista Rct, no. 71 , pp. 20-24, 2015.

[11] E. A. Quiroga-Montoya, S. F. Jaramillo-Colorado, W. Y. Campos-Muñoz and G. E. Chanchí-Golondrino, "Propuesta de una Arquitectura para Agricultura de Precisión Soportada en IoT", RISTI - Revista Ibérica de Sistemas e Tecnologias de Informação, no. 24, pp. 39-56, 2017. https://doi.org/10.17013/risti. $24.39-56$ 
[12] A. Liñán, A. Vives, A. Bagula, M. Zennaro and E. Pietrosemoli, "Internet de las cosas", Editado por: MarcoZennaro y Ermanno Pietrosemoli, 2015.

[13] M. Specht, B. Tabuenca and S. Ternier, "Tendencias del aprendizaje ubicuo en el Internet de las cosas", Campus Virtuales, vol. 2, no. 2, pp. 30-44, 2013.

[14] S. Mora-González, "Entendiendo el Internet de las cosas", Investig. TEC, no. 24, 2015.

[15] N. Figuerola, "Internet de las cosas", 2014. [Online]. Available at: https://pmqlinkedin.wordpress. com/about/internet-de-las-cosas/

[16] P. Sanmartín, K. Ávila, C. Vilora and D. Jabba, "Internet de las cosas y la Salud centrada en el Hogar", Revista Cientifica Salud Uninorte, vol. 32, no. 2, 2016. https://doi .org/10.14482/sun.32.2. 8954

[17] C. Lluch and N. Miranda, "El reto de conectar los objetos: Internet de las Cosas" , Profesiones, no. 139, p. $36,2012$.

[18] D. Meana-Llorian, C. G. García, B. G-Bustelo, J. M. Lovelle and V. H. García, "IntelliSenses: Sintiendo Internet de las Cosas", Iberian Conference on Information Systems and Technologies, CISTI, 2016. https://doi.org/10.1109/CISTI.2016.7521551

[19] K. Duarte Barón y C. Borrás Pinilla, "Generalidades de robots paralelos", Visión electrónica, vol. 10, no. 1, pp. 102-112, jun. 2016. https://doi.org/10.14483/22484728.11711

[20] Finnovating News, "Cómo el internet de las cosas está cambiando la banca", 2019. [Online]. Available at: https://www.finnovating.com/ news/internet-las-cosas-banca/

[21] S. Palit, A. Datta and V. López, "El desequilibrio socioeconómico consecuente de la industria de Internet de las Cosas", Punto de vista, vol. 7, no. 11, 2016. http://dx.doi.org/10.15765/pdv . v6i11.845

[22] Fundación Telefónica, "Smart Cities: un primer paso hacia la internet de las cosas", 2011. [Online]. Available at : https://www.aeiciberseguridad. es/descargas/categoria6/9704170.pdf

[23] Ovacen, "Internet de las cosas; Qué es y cuáles son sus ventajas y desventajas", 2014. [Online]. Available at: https://ovacen.com/ internet-de-las-cosas/

[24] J. Fermin and F. Guerra, "Internet de las Cosas", Perspectiv@s, vol. 10, no. 11, 2015.
[25] E. M. Saura, "Seguridad en Internet," Revista Publicaciones Navales, 2005.

[26] G. A. Ramirez-González, "Evaluación de introducción de internet de objetos en espacios de aprendizaje", thesis, Universidad Carlos III de Madrid, España, 2010.

[27] J. Ordieres-Meré, "BIG DATA e IoT: claves del modelo de negocio para la empresa industrial del siglo XXI" , Economía Industrial, no. 392, pp. 113-122, 2014.

[28] 20 minutos Editora, "El 'Big Data' y el 'Internet de las cosas', nuevos desafíos para la privacidad de las personas", 2015. [Online]. Available at: https://www.20minutos.es/ noticia/2360493/0/big-data/internet-cosas/ desafios-privacidad-personas/

[29] J. J. Palacios Rozo, H. E. Palacio Velásquez, and R. González Silva, "Educación versus tecnología y su convergencia hacia la IA", Rev. vínculos, vol. 15, no. 2, pp. 186-194, nov. 2018. https ://doi .org/10. 14483/2322939X. 14114

[30] D. Mourtzis, E. Vlachou and N. Milas, "Industrial Big Data as a Result of IoT Adoption in Manufacturing", Procedia CIRP, vol. 55, pp. 290-295, 2016. https://doi.org/10.1016/j. procir.2016.07.038

[31] D. Acosta, “¿El internet de las cosas es seguro?", 2014. [Online]. Available at: https: //www . deacosta. com/wp-content/uploads/2014/ 02/Empresario_Emprendedor_22_IoT.pdf

[32] A. Tejero-López, "Seguridad en el Internet de las Seguridad en el Internet de las Cosas", 2014. [Online]. Available at: https://docplayer.es/ 8043437-Seguridad-en-el-internet-de-las-seg $\backslash$ uridad-en-el-internet-de-las-cosas-cosas . html

[33] C. A. Dussan Clavijo, "Políticas de seguridad informática" , Entramado, vol. 2, no. 1, pp. 86-92, 2006.

[34] CSIRT-CV, "Seguridad en internet de las cosas estado del arte", 2014. [Online]. Available at: http://www.csirtcv.gva.es/ sites/all/files/downloads/\%5BCSIRT-CV $\% 5 \mathrm{D} \%$ 20Informe-Internet_de_las_Cosas.pdf

[35] J.-A. Sánchez-Alcón, L. López-Santidrián and J.-F. Martínez, "Solución para garantizar la privacidad en internet de las cosas" , Profesional de la Información, vol. 24, no. 1, pp. 62-70, 2015. https ://doi .org/10. 3145/epi.2015.ene.08 
[36] Fundación Proydesa, "Las 4 barreras que Internet de las Cosas tendrá que derribar". [Online]. Available: https://www . proydesa.org/portal/index.php/noticias/

1629-las-4-barreras-que-internet-de-las-col sas-tendra-que-derribar

[37] M. Castro Sola, "Internet de las cosas. Privacidad y Seguridad. Internet las Cosas", thesis, Universidad de Jaén, España, 2016.

[38] D. Rodríguez-González, "Arquitectura y Gestión de la IoT”, Telem@tica, vol. 12, no. 3, pp. 49-60, 2013.

[39] Ó. I. Montiel, M. A. Ayala, y L. Ripoll, "Diseño y simulación de antena no resonante: guía de onda de ranuras para $30 \mathrm{GHz}$ ", Visión electrónica, vol. 10, no. 1, pp. 49-56, jun. 2016. https://doi.org/10. $14483 / 22484728.11611$

[40] J. A. Vargas, J. Arango, and L. G. Isaza Domínguez, "Instructional Strategy to Train Professors from the Civil Engineering Program in the Use of Information and Communications Technologies (ICTS) at the Villavicencio Campus of the Universidad Cooperativa de Colombia", ing. Solidar, vol. 10, no. 17 , pp. 161-174, 2014. https://doi.org/10.16925/in. v9i17.829

[41] E. O. Sosa, D. A. Godoy, N. Neis, G. Motta, R. Luft, D. Sosa, H. Bareiro and P. Quiñones, "Internet del futuro y ciudades inteligentes" , XV workshop de investigadores en ciencias de la computación, 2013.

[42] R. W. Budd, "Información, interacción, intercomunicación: Tejiendo la red global. El impacto de Internet en el futuro de la educación", ZER-Revista de estudios de comunicación, vol. 2, no. 2,1997 .

[43] J. Taravilla Herrera, "El futuro de la red: internet de las cosas", Memorias del $50^{\circ}$ Congreso de Filosofía Joven Horizontes de Compromiso: LA VIDA, Granada: Asociación de Jóvenes Investigadores en Ciencias Sociales, pp. 770-796, 2015.

[44] Gartner, "The internet of things", 2013. [Online]. Available at: https://www.gartner. com/newsroom/id/2621015
[45] D. L. Pinzón Niño, "Panorama de aplicación de internet de las cosas (IoT)", thesis, Universidad Santo Tomás, Colombia,2016.

[46] Fundación Telefónica, "Internet Industrial: Máquinas inteligentes en un mundo de sensores", 2016. [Online]. Available at: https://publiadmin.fundaciontelefonica. com/index.php/publicaciones/add_descargas? tipo_fichero=pdf\&idioma_fichero=_\&title= Internet+Industrial\&code $=500 \& l$ ang $=e s \& f i l e=$ Internet_industrial.pdf

[47] J. I. San José and J. M. Pastor-García, "Internet de las cosas e Interfaces de Usuario", Editorial Aldebarán, 2016.

[48] CISCO, "IPv6 y el Internet de las Cosas (IoT)", 2016. [Online]. Available at: https://community. cisco.com/t5/videos-wireless-mobility/ ipv6-y-el-internet-de-las-cosas-iot-webcast $\backslash$ -video/ba-p/3103939

[49] A. Angulo, F. Martínez, y G. López, "Almacenamiento de energía usando ultracondensadores en sistemas fotovoltaicos autónomos", Visión electrónica, vol. 11, no. 1, pp. 30-39, jun. 2017. https://doi.org/10.14483/ 22484728.12875

[50] D. Gascón, "Redes de Sensores Inalámbricos, la tecnología invisible" , Bit, no. 180, pp. 53-55, 2010.

[51] P. Espeso, "Las 3 tecnologías clave para el Internet de las cosas", 2015. [Online]. Available at: https://www . xataka.com/internet-of-things/ las-3-tecnologias-clave-para-el-internet-de\ -las-cosas

[52] M. C. Acosta Ponce, "Estudio del éstandar IEEE 802.15.4 ZIGBEE para comunicaciones inalámbricas de área personal de bajo consumo de energía y su comparación en el estándar IEEE 802.15.1 BLUETOOTH", thesis, Escuela Politécnica Nacional, Ecuador, 2006. 